the lower temperaturos; above room temperature there was littlo variation of characteristics. In most cases tho square-law depondence of curront upon voltage was obeyed ovor this whole temperature-range. High-speed switching characteristics of the diodes were described in a paper by A. M. Conning (University of Birmingham). For both 'switch-on' and 'switch-off' operation steady-state conditions were reached in a time less than 3 musec., the response time of the measuring equipment ; charge storage effects in the diodes were undetectable. The final paper of this session was given by G. T. Wright and discussed the design of a proposed amplifying dielectric triode, which should possess a high input resistance, a large gain-bandwidth product, and be relatively insensitive to temperature changes. Calculations showed that the presence of shallow trapping levels $(<0.30 \mathrm{eV}$.) should result in the mutual conductance at high frequencies ( $>10 \mathrm{Mc} . / \mathrm{s}$.) being many times greater than at audio frequencies.

The opening paper of the fifth session was given by W. J. Merz (R.C.A., Zurich) on the subject of ferro-electricity. Present ideas of basic mechanisms in 'soft' and 'hard' ferro-electrics were reviewed and outstanding problems such as nucleation and losses above the Curie point considered. In the following paper, by K. W. Plessner (British Dielectric Research, London) and R. West (United Insulator Division, T.C.C., Chessington), the influence of the chemical composition of high permittivity ceramics upon their electrical properties was discussed. The application of chemical processes on an industrial scale was then considered. J. H. Bruce and J. R. Balmer (Radio Research Establishment, Malvern) then discussed the need for thin-film capacitors and the suitability of an evaporation method for producing these. Experimental techniques and results for silicon monoxide capacitors wore described. The last paper of the session was given by R. C. Kell (G.E.C., Wembley), who discussed piezoelectric ceramics. It had been found that niobate ceramics retained their piezoelectric properties at temperatures considorably higher than ceramics based on bariun titanate and that their properties showed less variation with temperature. In particular, sodium-cadmium and leadbarium niobates were more suitable than barium titanate ceramics for use in vibration detectors, ultrasonic generators, and resonators for filter networks.

The final session of the conference included contributions from S. Duinker (Philips, Findhoven) on a square-loop ferrite device for the fast scanning of electroluminescent cross-bar systems; from D. W. G. Ballentyne (Siemens Ediswan, Harlow) on the possible explanation of electroluminescence as a disorder phenomenon; from R. M. Glaister (G. V. Planar, Ltd., Sunbury) on relaxation polarization dielectrics; from E. A. D. White (G.E.C., Wembley) on the effects of additives on the properties of barium titanate ceramics; from J. C. Burfoot (Queen Mary College, London), who discussed switching in ferroelectrics; from Mr. F. H. Stieltjes (Philips, Eindhoven), who discussed losses in ferro-electrics with particular reference to their use in parametric amplifiers ; and G. T. Wright on the trap content of dielectrics with particular reference to the character. istics of dielectric diodes.

The conference emphasized that very great potentialities exist for the exploitation of dielectrics in devices although only limited practical progress has yet been made. There is no doubt, however, that the number and diversity of outstanding problems make this a most attractive field for both fundamental and applied research.

G. T. WRIGHT

\title{
THE NATIONAL RESEARCH DEVELOPMENT CORPORATION OF GREAT BRITAIN
}

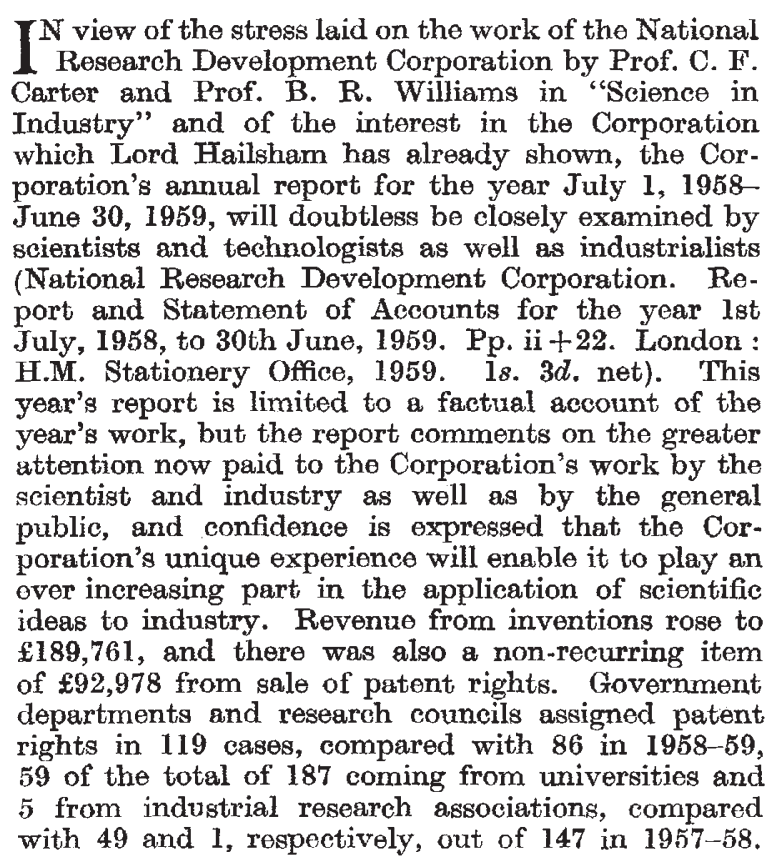

Of 681 inventions communicated to the Corporation during the year, compared with 612 the previous year, 287 were from Government departments and research councils, 27 from Commonwealth official organizations, 60 from universitios, 8 from industrial research associations and 296 from private firms and individuals, 263 in the United Kingdom. Holdings of British and foreign patent applications totalled 2,794, including 419 United Kingdom patent applications and 580 granted patents, 820 overseas applications and 975 granted patents.

Among new projects initiated during the year or reaching a stage suitable for report are Dr. I. E. Bush's automatic apparatus for chemical treatment and scanning of chromatograms, which has speeded up procedure considerably ; the development of the new antibiotics called the cephalosporins, particularly cephalosporin $C$, which is resistant to destruction by penicillinase; Prof. E. C. Cherry's television compression system using a variable scanning velocity so adjusted as to keep the transmitted frequencies within a desired bandwidth. An experimental system based on a 30-line picture has been constructed, and a further experimental system operating on 405 lines is being developed. A contribution has been made towards the cost of equipment to assess a proposal for an improved rolling mill, using rolls supported in 
hydrostatic bearings, and the Council decided in September 1958 to sponsor the development of Mr. C. S. Cockerell's inventions relating to "Hovercraft", and has formed a subsidiary company, Hovercraft Development, Ltd., to be responsible for its interest in this project. Financial assistance is being provided to complete the development of equipment capable of continuously processing hides and so giving increased capacity allied to smooth-running production and control. As a result of arrangements made by the Corporation to develop and exploit a new type of ditch cleaning media, a British manufacturer is building five prototypes, and the test results of the National Physical Laboratory on the robust and reasonably effective stabilizer designed in 1956 have now been checked on a fullscale ship.

Reference is also made to further developments in a process for producing acetylene by partial combustion of methane, to satisfactory negotiations for financial support of the computer-controlled machine tool project to be taken over by more appropriate organizations; the completion of a further design study permitting detailed assessment of the economic advantage of Fanshawe's oil-well drilling rig, and of the initial three-year programme of work on the ion-exchange membrane project, under which a process has been developed for continuous electrochromatography. Considerable further development will be required before the hydrogen-oxygen fuel cell can be launched on a commercial basis. New licensing arrangements were set up with a leading ice-cream manufacturer, who is now in production for the project for a freezing mill after treatment with ultra-sonic waves and pouring into waxed paper containers, and the process appears to offer prospects in the Middle East. Following successful testing and demonstration of the prototype flexible container for transporting oil, seven others have been ordered for use in different parts of the world.

\title{
SOLAR STILLS IN IRAQ
}

\author{
By Dr. A. V. BRANCKER \\ College of Science, University of Baghdad
}

$\mathrm{E}$ XPERIMENTS with solar stills and related units have been in progress at the College of Science, Baghdad, to provide fresh water for Bedouin communities, and to investigate the concentration of natural to heavy water.

Several designs of solar still were tested. Fig. 1 shows a still with a hemispherical 'Perspex' canopy. The base flange was held by screw clips on a gasket in a circular water channel. The complete unit included a flat-plate collector used as a preheater to increase the output of distilled water. The hemispherical still and a prismatic type with a glass canopy have been in continuous operation without maintenance since 1956 . Only recently have fine superficial cracks appeared in the 'Perspex'. In other respects these stills, of essentially simple design, have been satisfactory. Curves of water yield versus time and temperature versus time curves for the hemispherical 'Perspex' and prismatic glass stills, with no preheating, are plotted in Fig. 2. The effect of dropwise condensation on the 'Perspex' unit and back reflexion is shown by the relative positions of the curves. The total water output and the dimensions of the stills are given in Table 1.

On the basis of $3 \cdot 60$ litres or 0.79 gal. per square metre per day, the output, for a coverage of 1 acre, would be some 3,200 U.K. gal./day. Similar results were obtained by Lof ${ }^{2}$ at 0.69-1.07 gal./sq. metre/ day. In alternative units, the amount of water from a solar still is approximately $1 \mathrm{lb} . / \mathrm{sq}$. $\mathrm{ft}$./day.

In addition to providing freshwater for small communities, in remote areas, another application is being considered. Thus, natural water contains 1 part of heavy water in $6-7,000$ parts; therefore,

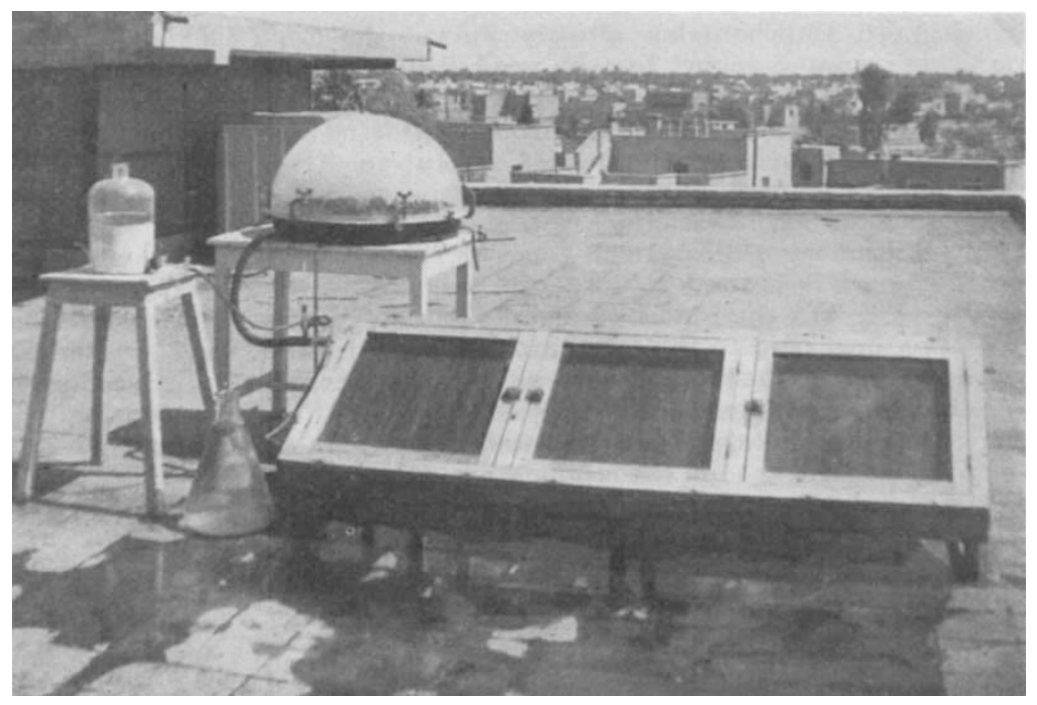

Fig. 1 